\title{
Promoting Post-Formal Thinking In A U.S. History Survey Course: A Problem-Based Approach
}

Charles T. Wynn, Kennesaw State University, USA

Richard S. Mosholder, Kennesaw State University, USA

Carolee A. Larsen, Kennesaw State University, USA

\begin{abstract}
This article presents a problem-based learning (PBL) model for teaching a college U.S. history survey course (U.S. history since 1890) designed to promote postformal thinking skills and identify and explain thinking systems inherent in adult complex problem-solving. We also present the results of a study in which the outcomes of the PBL model were compared to the outcomes of the same course taught with traditional lecture and discussion. The PBL model was more effective in scaffolding learning so that students recognize and practice postformal thinking dynamics and in facilitating self-reported student perceptions of increased course engagement and content relevance. We offer recommendations for implementing PBL in social science survey courses.
\end{abstract}

Keywords: Postformal Thinking; Metacognitive Reflection; PBL; History Education

\section{INTRODUCTION}

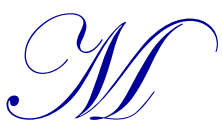

uch of the recent scholarship on teaching and learning (SoTL) of history has focused on moving away from a content coverage model in survey courses toward instructional methods that engage students in the practice and cognitive habits of the historian's craft (Andrews, 2009; Calder, 2006; Coventry et al., 2006; Jeffry, 2003; Stearns, 1993; Sipress \& Veolker, 2011). Calder (2006) described this signature pedagogy as one that requires students to "do, think, and value what practitioners in the field are doing, thinking, and valuing" (p. 1361). Sipress and Voelker (2011) referred to this recent instructional thrust as a "pedagogical countermovement" (p. 1051), in which the development of historical thinking skills becomes the primary goal of the survey course. Westhoff (2013) described historical thinking as the second of three fronts that created "a perfect storm" (p. 3), which helped to reshape U.S. survey courses over the last 2 decades; the Internet and the release of the 1994 U.S. History Standards were the other two fronts. This reshaping has resulted in historical thinking and related cognitive skills, becoming a central focus of many U.S history survey courses at both the secondary and college levels. VanSledright (2014) offered a model of learning history that identified historical thinking as the strategic knowledge necessary to do history and engage in domain specific cognitive efforts, which include "searching out evidence, assessing the sources for what they may offer, making sense of the perspectives of the sources' authors, judging an author's reliability in making reputable claims---in service of answering historical questions of interest" (p. 6).

The U.S. history survey course plays a key role in most general education curricula, by helping students achieve outcomes often framed around critical thinking and participatory citizenship. Laville (2011) described how a historical thinking-based pedagogical approach aligns well with these outcomes:

Such an approach encourages the development of those intellectual and affective qualities that students will need in the exercise of their civil responsibilities. It calls upon the critical faculties common to historians their ability to isolate a problem, analyze its component parts, and offer an interpretation - as well as their qualities of curiosity, empathy, and so forth, all of them built upon a solid foundation of analytical reasoning. (p. 166) 
Wynn (2015), however, questioned the sustainability of historical thinking skills practiced in a U.S. history survey:

Assuming these students develop historical thinking to some competent degree over a semester or two, the question arises to what extent they will be able to maintain and apply domain-specific knowledge and reasoning skills beyond the context of the survey course? (p. 29)

Bain (2009) posed a similar question: "I have no idea what happens when students move into other settings. Does any of this have staying power, or is it merely contextualized to 'that is how we studied history in our freshman year?"” (p. 166).

Laville (2011) addressed the extent to which historical thinking skills will be useful to students as they confront broader, real world problems and issues beyond their survey course experiences:

We must not forget that these pupils we are preparing in class will be less likely, as adults, to deal with history texts than to use their skills as citizens in the identification of social problems, the analysis of areas of conflict, the rational calculations of risks and rewards, and the weighing of competing interests, and in their personal decisions on the issues of the day. (pp. 166-167)

Examining the multi-systematic nature of advanced problem-solving helps to define the broader cognitive dynamics necessary to successfully confront complex problems and issues. Sinnott and Johnson (1996) argued for problembased university curricula that promote the development of these broader, more advanced cognitive skills among students, e.g. those found in postformal thinking operations that involve multiple thinking systems. The Association of American of Colleges and Universities (AAC\&U; 2015) established principles and guidelines for developing general education curricula and experiences that guide students to "demonstrable, portable proficiencies aligned to widely valued areas of twenty-first century knowledge and skill," including the development of sustainable problemsolving skills "through problem-centered work on significant issues relevant to their interests and aims" (p. 3). We argue that the college and university U.S. history survey courses can be pedagogically and epistemologically structured to promote these proficiencies and the inherent advanced thinking skills.

In this article, we expand on previous research (Wynn, Mosholder, \& Larsen, 2014) that indicated that PBL with explicit metacognitive reflection promotes the practice and acquisition of postformal cognitive skills among firstyear learning community students and non-learning community students in a U.S. history survey course context. First, we identify and explain specific targets of advanced cognition inherent in complex problem-solving. Second, we provide a detailed description of our PBL metacognitive reflection model through which these systems/skills are identified and practiced. Lastly, we present results from the current study that measured the effects of the instructional model on the development of postformal thinking skills among U.S. history survey students (pre/posttest differences). In this study we compare pretest-posttest differences between U.S. history survey students who were taught using the PBL method, and students who were taught using TLD, and we measure the model's impact on student perceptions of course engagement and content relevance.

\section{Formal Thinking, Postformal Thinking, and Adult Complex Problem-Solving}

Our basic goal in confronting students with complex problem-solving experiences in the context of a U.S. history survey course is to guide them to break away from a more closed systems problem-solving approach. Closed systems problem-solving is very common for students who have attained formal thinking skills, or the ability to apply logical operations to abstract problems (Inhelder \& Piaget, 1958). Closed systems problem solvers often fail to recognize various relevant variables and important contextual aspects of the problem or issue at hand and presume a logical consistency within a single logical system (Sinnott, 1998). This often leads them to expect to produce a single right answer that closely aligns with solutions to similar problems they have encountered in the past, while assuming that this right answer will hold in all similar circumstances in the future (Wu \& Chiou, 2008).

Students may also rely upon intuitive thinking when problem solving through an "if it feels right, it's right" dynamic. This approach tends to be much easier and feels more natural than applying the logical operations associated with formal thinking (Epstein, Pacini, Denes-Raj, \& Heier, 1996; Evans, 2008; Steinberg, 2007; 
Witteman, van den Bercken, Claes, \& Godoy, 2009; Wynn, 2010, 2015). Students must come to recognize the inadequacy of formal and intuitive thinking systems in solving complex problems in order to prompt a search for more adequate problem-solving systems (Basseches, 2005; Sinnott, 1998). These more adequate and advanced thinking systems are inherent in adult complex problem solving and are found in the postformal stage of reasoning (Arlin, 1984; Basseches, 1984; Chiou, 2008; Commons, Ross, \& Miller, 2010; Commons \& Ross, 2008; LabouvieVief, 1985; Labouvie-Vief, Adams, Hakim-Larson, \& Hayden, 1983; Marchand, 2002; Perry, 1970; Reigel, 1975; Sinnott, 1989, 1998) which includes two substages.

Relativistic thinking is the first sub-stage, described by Sinnott (1998) as the recognition that complex problems often can prompt many ideas about what is true and relevant, and that these ideas can be conflicting. Context and perspective also become relevant in this stage. What is believed to be true in one context or from one perspective might not be true from another (Chiou, 2008). Kahlbaugh \& Kramer (1995) studied the development of relativistic thinking in late adolescents and young adults and concluded that people in these age groups are faced with an increasing number of personal, social and perhaps political challenges. These challenges may prompt a cognitive adaptation toward a more relativistic cognitive dynamic. Because their fixed truths and dualistic categories no longer provide adequate answers, relativistic thinkers consider the multidimensional nature, multiple truths, and contextual characteristics of problems and issues as they seek solution alternatives. Relativistic thinkers also recognize that some problems and issues do not have acceptable or workable solutions (Chiou, 2008; Sinnott, 1998).

Dialectical thinking is the second and most advanced sub-stage of postformal thinking and adult problem solving (Basseches, 1984, 1989, 2005; Ho, 2000; Ledbetter, 1986; Riegel, 1975; Sinnott, 1998). Moving beyond relativistic thinking, dialectical thinkers recognize that contradictory positions within a complex problem or issue are connected, and must be considered, to develop solutions. They search for and recognize gaps in the logic of opposing positions or perspectives, including inconsistencies and contradictions, and seek to understand how and why the positions are constructed and defended. These gaps prompt the utilization of a variety of cognitive systems (intuitive, formal, relativistic, dialectical), resulting in solution alternatives reflecting higher levels of understanding and cognition (Ho, 2000). In addition, dialectical thinkers recognize that any solution to, or stabilization of, a complex problem or issue will always be subject to changes and challenges because this is the nature of the tensionto resolution-to tension cycle dynamic of issues (Blouin \& McKelvie, 2012). Vukman (2005) summarized the relativistic and dialectical characteristics involved in postformal problem solving from the work of Kramer (1989, 1990) and Sinnott (1984, 1989):

- Acceptance of relativism: recognition that personal perspective is only one of many potentially valid viewpoints on reality;

- Understanding and acceptance of contradiction and the ability to handle conflicting ideas and systems: the realization that contradiction and complexity may be inherent features of reality; tolerance is gained through an appreciation of the dialectic relationship between opposing systems;

- Integration of systems/frames of reference: a synthetic form of thinking that integrates several opposing systems into an abstract whole and actually transcends idiosyncratic perspectives (Kuhn, Cheney, \& Weinstock, 2000). (p. 212)

Guiding students to practice these broad, postformal problem-solving skills is a central focus of our instructional model, along with the purposeful application of content knowledge and the development and application of domainspecific cognitive skills like historical thinking.

\section{The Role of Domain-Specific Cognitive Skills within Adult Complex Problem-Solving}

The metacognitive dynamic described in Demetriou, Spanoudis, \& Mouyi's (2011) overarching stage theory also offers a useful conceptual framework that influenced our instructional model. This theory helped define and explain the multi-systematic nature of postformal thinking, as well as the role of discipline specific cognitive skill sets (like historical thinking) within the broader framework of adult complex problem-solving, and emphasized the importance of capitalizing on developmental milestones for learning. 
A student who has reached adult learning milestones would recognize that real-world problem solving may require solving a series of subproblems related to the overarching problem at hand, each of which may require domainspecific reasoning (e.g., historical thinking, mathematical estimations of relations) before a solution alternative can be selected.

Students must be given the opportunity to think on and assemble complex hierarchical problems where hierarchies are embedded into each other. Working on problems of this kind may enable students to differentiate between the various cognitive systems and processes activated in problem solving. (Demetriou et al., 2011, p. 645)

This metacognitive dynamic helped guide the development of the reflective component of our instructional model and helped us better understand the importance of guiding students to recognize how discipline-specific cognitive skill sets, like historical thinking, which clearly involves postformal thinking dynamics, may be purposefully identified, selected, and utilized in the broader context of real-world adult problem solving.

\section{Promoting Postformal Thinking: A Problem-Based Learning Instructional Framework}

The recognition that exposure to complex problems, along with a modeling and scaffolding process, guides students to move toward a more postformal cognitive framework (Basseches, 2005), helped us to recognize an epistemological alignment with PBL. PBL is based on authentic, real-world problems (Hmelo-Silver, 2004), and encourages students to use advanced thinking processes (Lenkauskaite \& Mazeikiene, 2012). Originally used in medical education, PBL has been utilized in a variety of settings ranging from middle school through all levels of postsecondary education (Hmelo-Silver, 2004). PBL has been shown to increase content knowledge retention and to improve student ability to transfer problem-solving processes into both new and more complex circumstances (Blumberg, 2000; Cognition and Technology Group at Vanderbilt [CTVG], 1997; Maxwell, Bellisimo, \& Mergendoller, 2001; Mergendoller, Maxwell, \& Bellisimo, 2006). Skillful PBL instructors model problem-solving systems and guide students through thinking processes. These behaviors provide the cognitive scaffolding or guidance necessary to promote advanced PBL skills, such as postformal operational problem-solving skills (Wynn, 2010, 2015; Wynn et al., 2014). The addition of peer-to-peer interaction can provide a collaborative learning environment that prompts more capable peers to take on a similar tutorial role (Hmelo-Silver, 2004).

When using our model as intended, instructors will demonstrate to students how to recognize, select, and apply a variety of cognitive systems based on the characteristics of the problem or issue at hand. These can include the intuitive, formal, relativistic, and dialectical systems previously described as well as domain-specific systems like historical thinking. Once this framework has been presented, the instructor guides students through a reflective process in which they judge which systems were more useful or successful, and why. This metacognitive reflection guides students to monitor and direct the processes of problem-solving, and helps them construct a cognitive selfawareness that is necessary in the development of postformal thinking and problem-solving operations (Hacker, 1998; Hmelo-Silver, 2004; Wynn, 2010, 2015; Wynn et al., 2014), in contrast to what Bartos and Banks (2015) defined as an "osmosis model" (p. 36), in which advanced thinking skills are somehow absorbed through participation in lectures and class activities.

The PBL procedures used in our study are outlined as follows, and were based on Wynn's (2010, 2015; Wynn et al., 2014) PBL instructional model. These activities may be accessed through the link provided in Appendix A.

Step 1 - Problem Development: Our primary focus during this phase was to peak student interest (create a need to know more), establish "stakeholdership," and explicitly portray the problem/issue as multidimensional. We presented problems/issues through story-telling, video clips, data presentations, and readings (including primary sources).

Step 2 - Initiation of PBL Events-Argumentation and Student Inquiry: Our initial focus was to guide students to define the problem, identify its multidimensional or multi-truth characteristics, and identify the need for domain specific knowledge and processes (discipline specific skill applications, inquiry, etc.) and broad thinking systems (intuitive, formal, relativistic, and dialectical). We then initiated a decision- 
based/argumentation structure (Jonassen, 2012) to prompt students to generate arguments, and allow them to work to resolve conflicts and contradictions among competing positions. This was done primarily through historical simulations and current issue presentations. At the conclusion of the simulations and issue presentations, students identified what they learned about the problem/issue and the inherent contradictory or opposing positions, and identified what additional information they needed in order to develop solution alternatives.

Step 3 - Problem Solution: Students generated solutions/decisions and examined their "fit," then proposed the most appropriate one, and evaluated its historical or potential consequences. We then guided students to compare their solution/decision to the actual historical outcome and its legacy, and the impact of change. Solutions/decisions on current issues were analyzed base on potential for success. We assigned a concluding opinion essay, and guided students through debriefing, which included a review of the content, concepts, and skills encountered and used during the problem solving cycle. Students then reflected on the types of thinking strategies they used, and the successes or failures of each, through the use of a metacognitive reflection questionnaire (Appendix B; Wynn, 2010; Wynn et al., 2014; Wynn, 2015).

\section{RESEARCH QUESTION AND HYPOTHESES}

Based on this literature review and previous research (Wynn et al., 2014), we hypothesized that participation in multiple PBL activities that contained a metacognitive reflection element would have a significant relationship with the development of postformal thinking skills among U.S. history survey course students. We also hypothesized that PBL students would report an increase in their level of course engagement and in their perception of course content relevance compared to students in different sections of the same course taught primarily through lecture and discussion (TLD). Therefore, our research tested the following null hypotheses:

1. There will be no significant difference in cognitive growth, as measured via pretest-posttest changes in postformal thinking skills, between students in PBL sections of a U.S. history survey course and students in different sections of the same course taught primarily through lecture and discussion.

2. There will be no significant difference in self-reported postformal experience, as measured via an end of course questionnaire, between students in PBL sections of a U.S. history survey course and students in different sections of the same course taught primarily through lecture and discussion.

3. There will be no significant difference in self-reported levels of course engagement, as measured via an end of study questionnaire, between students in PBL sections of a U.S. history survey course and students in different sections of the same course taught primarily through lecture and discussion.

4. There will be no significant difference in self-reported level of course content relevance, as measured via and end of study questionnaire, between students in PBL sections of a U.S. history survey course and students in different sections of the same course taught through primarily lecture and discussion.

\section{METHODS}

Three sections of the U.S. history survey course (America since 1890: HIST 2112) were taught by one of our research team members using our PBL method, and two sections of the same course were taught by another instructor using TLD. The three PBL sections included a total of 87 students ( 25 students in section one, 22 students in section two, and 40 students in section three). The two smaller PBL classes were first-year learning community sections, meaning that they were paired with a first-year seminar course. Students self-selected their section of HIST 2112 during fall registration. HIST 2112 is a required general education course at our institution. The topical outline, activities, assessments, and dates of implementation were identical in each of the three PBL sections, and included nine primary instructional topics or units, with six of the nine instructional units culminating in PBL activities. Each PBL activity took one or two 75-minute class periods to complete. A list of the nine units and the six PBL activities along with the URL to access the activities is provided in Appendix A. The other instructional methods used in the PBL-based course focused on providing context for the PBL activities and included lecture, discussion, and guided questions (Reisman \& Wineburg, 2009). The entire course was designed to examine and analyze U.S. history through a progressive, conservative dialectal framework. Of the 87 PBL students, 78 agreed to participate in the study. 
The control group included two sections of HIST 2112 with 112 students each, taught primarily by a traditional lecture and discussion (TLD) method wherein the instructor assigned students approximately a chapter a week from the course text, and provided PowerPoints that highlighted key content/concepts/ideas. The two TLD sections also included one reaction essay assignment based on one of three documentary films watched in class, all from the PBS American Experience series: The Civilian Conservation Corps (Samuals \& Stone, 2009), My Lai (Samuals \& Goodman, 2010), and The Triangle Fire (Samuals \& Espar, 2011). The students were asked to address three questions in the essay: What was the film about? How did it connect to the era being studied? How did it enhance, or not, your understanding of the era/topic? A connecting theme of the course was "rhetoric vs. reality." Of the 224 students in the two TLD sections, 118 agreed to participate in the study.

\section{Measures}

Postformal Thought (PFT) Questionnaire. We administered the PFT (Sinnott \& Johnson, 1997) to measure participants' levels of postformal thought. (See Cartwright, Galupo, Tyree, \& Jennings, 2009 for discussion of reliability and validity.) The questionnaire included 10 statements that represent a different operation of postformal thinking. Participants responded to each statement by indicating the extent to which it characterized their own thinking $(7=$ very true, $1=$ not true $)$. The sum of the 10 items provided a summary PFT score for each participant. The pretest was administered during the first class of fall semester in the PBL sections, and during the second class in TLD sections. Posttests were administered on the last day of classes in each section. The PFT is included as Appendix C.

End of Study Questionnaire (ESQ). We administered the ESQ to participants after all other data were collected. ESQ questions included a Likert rating of participants' level of engagement in HIST 2112 (Question 1), a Likert rating on the level of relevance of course content and topics (Question 3) a question that prompted participants to reflect on the extent to which their experience in the HIST 2112 affected their ability to think critically (Question 4), and one on the extent to which students believed that these skills would be useful beyond the course (Question 5). The ESQ is included as Appendix D.

\section{Methods of Analysis}

To test our PBL instructional model's impact on the development of postformal thinking skills among U.S. history survey students, we conducted two analyses: one quantitative, and one incorporating mixed-methods. The quantitative analysis included a comparison of PFT mean-normalized gain scores of the PBL and TLD sections. The normalized gain score is "the ratio of the actual average gain $(\%<$ post $>-\%<$ pre $>)$ to the maximum possible average gain $(100-\%<$ pre $>$ )" (Hake, 1998, p. 64). A one-way analysis of variance (ANOVA) was conducted to examine the holistic difference in postformal thinking between the two groups.

We used mixed methods to analyze responses to short-answer ESQ questions four and five. We used direct content analysis or deductive category application (Mayring, 2000; Potter \& Levine-Donnerstein, 1999) to identify and define two operational definitions (see Appendix E) for two problem-solving systems: (a) closed systems-CS; and (b) postformal operational systems-PF. Two faculty researchers and two student researchers coded all responses individually. Student responses were coded as self-reported PFT experience if the comment indicated the utilization of characteristics of relativistic and/or dialectical operations. For example, "I think my way of thinking has evolved in a way that I now look at multiple solutions and sides to issues that I originally did not see." The third researcher examined the coded responses and identified categorized students as using postformal reasoning if three of the four coders $(75 \%)$ agreed to that categorization. The third researcher then created a dichotomous nominal variable $(1=$ self-reported postformal-related experience in question four or five, $0=$ no self-reported postformal-related experience in question four or five) in order to conduct an independent T-Test to examine the difference in selfreported experience with PFT. An independent T-Test was also conducted to examine the differences in self-reported levels of course engagement (ESQ Question 1) and self-reported levels of course content relevance (ESQ Question 3) between the two groups. 


\section{RESULTS AND DISCUSSION}

Pretest PFT means of the PBL sections $(n=64)$ and TLD sections $(n=109)$ indicated that there was no significant difference in PFT between the two groups at the beginning of the study (PBL $M=50.77, S D=7.61$; TLD $M=$ $51.12, S D=6.32$ ), while the posttest means showed a greater mean PFT score for the PBL group (PBL $M=54.52$, $S D=6.45$; TLD $M=51.76, S D=8.02)$. One-way ANOVA data for the normalized gain scores (Bao, 2006) showed a significantly greater net mean gain of 3.75 between pre- and posttest PFT scores in the PBL sections compared to a .64 mean gain in the TLD sections, $\mathrm{F}(1,171)=8.84, p<.003$, and a significantly greater normalized gain in the PBL sections (.079) than TLD sections (.025), $\mathrm{F}(1,171)=5.85, p<.017$. We also analyzed PFT data to determine if there were mean gain differences between the smaller PBL learning community sections and the regular PBL section. There was no significant difference, with net gain means of 3.23 and 4.38 respectively.

The significant results of the direct content analysis of ESQ questions four and five align well with the pre- and post-PFT results. Independent $t$-test data showed a significantly greater mean of self-reported postformal thinking experiences occurring in the PBL sections $(n=78, M=.87, S D=.34)$ compared to the TLD sections $(n=118, M=$ $.24, S D=.48), t(193)=10.95, p<.000$. We thus rejected Hypothesis 2 . Taken together, these results indicate that our PBL instructional model yielded significantly greater postformal thinking scores compared to TLD; these results confirm those obtained by Wynn et al. (2014).

We found the results of the analyses of comments from ESQ questions four and five compelling. The common themes noted from PBL student comments included their ability to recognize and better understand multiple truths or perspectives when confronted with a complex problem or issue, and the importance of utilizing multiple perspectives in the problem-solving and decision-making process. PBL students also recognized the applicability of postformal thinking systems beyond the confines of their U.S. history survey course. A sampling of PBL student comments reflecting these themes is presented in Appendix F.

Of the 118 TLD students who provided comments, 28 comments were coded as indicating some level of experience with postformal thinking dynamics, specifically with recognition and utilization of multiple perspectives on historical events and the focus on "rhetoric vs. reality" as a course theme. We hypothesized that the reaction essay assignment, and the perspectives introduced through the rhetoric vs. reality theme of the course, may have prompted the TLD student comments that indicated relativistic considerations. A sampling of these comments are also provided in Appendix F.

Independent $t$-test data for responses to ESQ question one, which measured self-reported levels of course engagement, showed PBL students reported significantly greater levels of engagement $(n=78, M=4.25, S D=.73)$ compared to TLD students $(n=116, \mathrm{M}=3.29, S D=1.06), t(191)=6.87, p<.000$. Therefore, we rejected Hypothesis 3.

The similar engagement results from Wynn et al. (2014) confirm our conclusion that the primary difference in level of engagement between the two groups may be explained by the explicit learner-centered, social learning dynamic that is facilitated by our PBL model in comparison to the more teacher-centered learning dynamic of the TLD sections. Our comparison of PBL and TLD student comments offered a compelling glimpse into how the two groups differed in their perceptions of what constitutes course engagement in general. We selected and reviewed comments from students in both groups who scored their levels of engagement as fours or fives. TLD students tended to frame explanations of engagement within a traditional teacher-centered learning dynamic compared to the more learnercentered, active explanations offered by PBL students. For example, PBL student \#5 stated, "I was actively forming opinions on subjects through information presented by classmates as well as my instructor, unlike previous courses I have taken where all information presented comes from a singular source, the teacher." TLD student \#136 stated, "I came to almost every class this semester except maybe two. I take notes and have done well on the tests. If I wasn't engaged, I would not be doing well." A comparative sampling of PBL and TLD student comments from ESQ question one is provided in Appendix F.

Independent $t$-test data for responses to ESQ question three, which measured self-reported perceptions of content relevance, again showed PBL students reporting significantly higher ratings $(n=78, M=4.77, S D=.51)$ than TLD students $(n=116, M=4.13, S D=1.24), t(191)=4.24, p<.000$. This led us to reject Hypothesis 4 . 
The PBL course was designed to guide students not only to connect the past to the present, but also to apply the advanced problem-solving skills gained through confronting contextualized historical problems to current issues, including The Affordable Care Act; Immigration Reform; Debt, Spending, Taxes, and a Balanced Budget Amendment; Climate Change Cap and Trade; and Minimum Wage. In general, PBL student comments indicated that their high ranking of content relevance was due to their recognition of this dynamic. For example, PBL student \#19 stated, "In this class we have dealt with immigration, civil rights, and even ISIS. It [content] was very relevant because we dealt with these topics using the same lens as we did when dealing with historical events."

\section{CONCLUSIONS AND RECOMMENDATIONS}

Results from the current study confirm the findings of Wynn et al. (2014). Our PBL instructional method, which includes metacognitive reflection, has a significant relationship with the development of postformal thinking skills compared to a TLD method in a U.S. history survey course context. We believe that several factors may explain these results. Basseches (2005) and Sinnott (1998) argued that individuals must be confronted by the diverse perspectives, multiple truths, and contradictions inherent in complex problems and issues in order to first recognize the inadequacy of formal/absolutist thinking, and second, to begin seeking more adequate/advanced thinking systems. Our PBL model was designed to prompt metacognitive reflection in a way that allows instructors to guide students toward the recognition and practice of multiple thinking systems and to judge the extent to which these systems are adequate for successfully addressing complex problems and issues. We facilitated these processes through an initial thinking systems tutorial at the end of the first PBL activity, followed by the administration of the metacognitive reflection questionnaire. We also administered the metacognitive questionnaire after the second PBL activity. PBL students began recognizing the dynamics of intuitive, analytical, relativistic, and dialectical thinking, as well as domain-specific thinking systems, like historical thinking, very early in the semester and they learned relatively quickly how to judge the extent to which these systems were usefully practiced. Most PBL students were able to initiate metacognitive reflection without the use of the questionnaire after the third PBL activity. We believe this working knowledge of the multiple thinking systems practiced in advanced problem-solving helps explain the greater postformal thinking gains among PBL student.

We recognize that U.S. history survey course instructors, and survey course instructors in general, might be hesitant to take on the task of guiding the metacognitive reflection process. It takes instructional time and some working knowledge of thinking systems. The metacognitive reflection questionnaire provided in Appendix B is offered to introduce the thinking systems involved in problem solving and decision making and to facilitate reflective discussions. Instructors do not have to be experts to guide the process.

Two other factors we believe are significant in explaining the holistic differences between the PBL and TLD sections involve class size and content coverage. The social learning dynamics that are so critical to the success of PBL activities are more easily facilitated in smaller classes (Wynn, 2010, 2015; Wynn et al., 2014). TLD student \#163 framed the impact of class size on engagement in the following comment on ESQ question one: "It is hard to be fully engaged in a course that covers so much material and has such a large class size. We are only given the ability to take notes and give a few responses." We concur with this observation and recommend that the chronological coverage approach be significantly adapted to accommodate a workable number of activities if instructors want to implement PBL. Each instructor should select "turning-point" problems and issues on which to develop PBL activities, and should determine the number of activities to include, recognizing that confronting students with multiple problems or issues may be necessary to facilitate more adequate and sustainable thinking skills. We recommend a maximum 40 -student class size for PBL sections.

We also recommend that current issues be included as the basis of PBL activities during the last phase of a PBLbased U.S. History II survey course; students may apply the postformal problem-solving skills to current issues in the manner that they practiced with historical issues. PBL student comments on ESQ question three clearly indicated that students attributed content relevance, in part, to their engagement with contemporary problems and issues that may directly affect their lives. This focus also aligns well with the AAC\&U (2015) general education principle cited earlier regarding students gaining proficiencies "through problem-centered work on significant issues relevant to their interests and aims" (p. 3). Confronting current issues may also help students recognize the applicability of postfomal thinking systems and even historical inquiry, beyond the confines of their U.S. history survey courses. 


\section{LIMITATIONS AND CHALLENGES}

Several limitations of the current study should be noted. First, two different instructors taught the PBL and TDL sections, possibly leading to the occurrence of uncontrolled extraneous events. Second, the relatively small sample size in both the PBL and TLD sections may limit the generalizability and utility of the findings. Third, as stated previously, class size is certainly a factor in successfully implementing PBL activities. The large class size in both TLD sections could affect the success of TLD instructors facilitating more advanced thinking skills, engagement, and perceptions of content relevance among students. Studies measuring outcomes in PBL and TLD sections of similar size should be conducted. We also note the fact that the two smaller PBL sections were affiliated with learning communities, which may be a confounding variable.

A significant challenge in implementing a PBL-based U.S. history survey is the amount of time and effort necessary to construct the PBL activities. The researcher who taught the PBL sections spent several months developing the activities and gathering the necessary resources and primary documents to support the activities and related assignments. With that noted, we consider the social learning environment and the resulting levels of student engagement, content relevance, and advanced thinking skills that are facilitated through our PBL instructional model to be well worth the effort.

We encourage other SoTL scholars in history and other disciplines to test the impact of PBL and metacognitive reflection on their survey course students. As stated earlier, AAC\&U (2015) is calling for problem-based college curricula to guide students toward the development of useful and sustainable problem-solving skills. We believe general education curricula should provide meaningful and relevant experiences that promote demonstrable and sustainable proficiency in postformal thinking. We offer our PBL instructional model as an option that survey course instructors may use to facilitate these skills. In this time of intense political polarization, and given the everincreasing issues that affect the well-being and security of all of us, such cognitive and deliberative capacities are sorely needed.

\section{ACKNOWLEDGEMENT}

Our study was supported by a grant from the Center for Excellence in Teaching and Learning at Kennesaw State University.

\section{AUTHOR BIOGRPAHIES}

Charles T. Wynn is Assistant Professor of History and History Education at Kennesaw State University in Kennesaw, Georgia with research interests in the cognitive dynamics of teaching and learning history. He teaches survey and upper level history courses as well as graduate and undergraduate history/social studies methods courses.

Richard S. Mosholder is Associate Professor of Psychology in the Department of First-Year and Transition Studies at Kennesaw State University. His research interests include the teaching and learning of academic and life skills to facilitate success for marginalized groups. He teaches first-year seminars within learning communities and undergraduate psychology courses.

Carolee A. Larsen is Assessment Director for University College at Kennesaw State University. Her research interests include research methods and assessment, and legal support and policy discourse. She teaches sociology and global studies first-year seminars. 


\section{REFERENCES}

Andrews, S. D. (2009). Structuring the past: Thinking about the history curriculum. The Journal of American History, 95(4), 1094-1101.

Arlin, P. K. (1984). Adolescent and adult thought: A structural interpretation. In M. L. Commons, J. D. Sinnott, F. A. Richards, \& C. Armon (Eds.), Beyond formal operations: Late adolescent and adult cognitive development (pp. 256-271). New York, NY: Praeger.

Association of American Colleges and Universities. (2015). General education maps and markers: Designing meaningful pathways to student achievement. Washington, DC: Author.

Bain, R. B. (2009). Into the breach: Using research and theory to shape history instruction. Journal of Education, 189(1-2), 159167.

Bartos, S. E., \& Banks, A. P. (2015). How do students learn critical thinking? Challenging the osmosis model. History \& Philosophy of Psychology, 16(1), 36-40.

Bao, L. (2006). Theoretical comparisons of average normalized gain calculations. American Journal of Physics, 74(10), 917-922.

Basseches, M. (1984). Dialectical thinking and adult development. Norwood, NJ: Ablex.

Basseches, M. (1989). Dialectical thinking as an organized whole: Comments on Irwin and Kramer. In M. L. Commons, J. D. Sinnott, F. A. Richards, \& C. Armon (Eds.), Adult development volume 1: Comparisons and applications of developmental models (pp. 161-178). New York, NY: Praeger.

Basseches, M. (2005). The development of dialectical thinking as an approach to integration. Integral Review, 1(47-63).

Blouin, P. S., \& McKelvie, S. J. (2012). Postformal thinking as a predictor of creativity and of the identification and appreciation of irony and metaphor. North American Journal of Psychology, 14(1), 39-50.

Blumberg, P. (2000). Evaluating the evidence that problem-based learners are self-directed learners: A review of literature. In D. H. Evensen \& C. E. Hmelo (Eds.), Problem-based learning: A research perspective on learning interactions (pp. 199226). Mahwah, NJ: Lawrence Erlbaum.

Calder, L. (2006). Uncoverage: Toward a signature pedagogy for the history survey. The Journal of American History, 93(4), $1358-1370$.

Cartwright, K. B., Galupo, M. P., Tyree, S. D., \& Jennings, J. G. (2009). Reliability and validity of the complex postformal thought questionnaire: Assessing adults' cognitive development. Journal of Adult Development, 16, 183-189.

Chiou, W. (2008). College students' role models, learning style, preferences, and academic achievement in collaborative teaching: Absolutist versus relativistic thinking. Adolescence, 43(169), 129-142.

Cognition and Technology Group at Vanderbilt [CTGV]. (1997). The Jasper Project: Lessons in curriculum, instruction, assessment, and professional development. Mahwah, NJ: Lawrence Erlbaum.

Commons, M. L., \& Ross, S. N. (2008). What postformal thought is, and why it matters. World Futures: The Journal of General Evolution, 64, 321-329.

Commons, M. L., Ross, S. N., \& Miller J. G. (2010). Why postformal stages of development are not formal, but postformal. Integral World: Exploring Theories of Everything. Retrieved from http://www.integralworld.net/commons $1 . h t m l$

Coventry, M., Felton, P., Jaffee, D., O’Leary, C., \& Weis, T., with McGowan, S. (2006). Ways of seeing: Evidence and learning in the history classroom. The Journal of American History, 93(4), 1371-1402.

Demetriou, A, Spanoudis, G, \& Mouyi, A (2011). Educating the developing mind: Towards an overarching paradigm. Educational Psychology Review, 23(4), 601-663.

Epstein, S., Pacini, R., Denes-Raj, V., \& Heier, H. (1996). Individual differences in intuitive-experiential and analytical-rational thinking styles. Journal of Personality and Social Psychology, 71, 390-405.

Evans, J. St. B.T. (2008). Dual-processing accounts of reasoning, judgment, and social cognition. Annual Review of Psychology, 59, 255-278.

Hacker, D. J. (1998). Definitions and empirical foundations. In D. J. Hacker, J. Dunlosky, \& A. C. Graesser (Eds.), Metacognition in educational theory and practice (pp. 1-23). Mahwah, NJ: Lawrence Erlbaum.

Hake, R. R. (1998). Interactive-engagement versus traditional methods: A six-thousand-student survey of mechanics test data for introductory physics courses. American Journal of Physics, 66(1), 64-74.

Hmelo-Silver, C. E. (2004). Problem-based learning: What and how students learn? Educational Psychology Review, 16(3), 235266.

Ho, D. (2000). Dialectical thinking: Neither Eastern nor Western. American Psychologist, 55(9), 1064-1065.

Inglis, J., \& Steele, M. (2005). Complexity intelligence and cultural coaching: Navigating the gap between our societal challenges and our capacities. Integral Review, 1, 36-46.

Inhelder, B., \& Piaget, J. (1958). The growth of logical thinking from childhood to adolescence: An essay on the construction of formal operational structures. New York, NY: Basic Books.

Jeffrey, J. R. (2003). The survey again. OAH Magazine of History, 17(3), 52-54.

Jonassen, D. H. (2012). Designing for decision making. Educational Technology Research \& Development, 60, $341-359$.

Kahlbaugh, P. E., \& Kramer, D. A. (1995). Relativism and identity crisis in young adulthood. Journal of Adult Development, 2 , 63-70.

Kramer, D. A. (1989). Development of an awareness of contradictions across the lifespan and the question of postformal 
operations. Adult Development, 1, 133-159.

Kramer, D. A. (1990). Conceptualizing wisdom: The primacy of affective-cognitive relations. In R. J. Sternberg (Ed.), Wisdom: Its nature, origins and development (pp. 279-313). New York, NY: Cambridge University Press.

Kuhn, D., Cheney, R., \&Weinstock, M. (2000). The development of epistemological understanding. Cognitive Development, 15, 309-328.

Labouvie-Vief, G. (1985). Intelligence and cognition. In J. E. Birren \& K. Warner-Schaie (Eds.), Handbook of the psychology of aging (2nd ed., pp. 500-530). New York, NY: Van Nostrand Reinhold.

Labouvie-Vief, G., Adams, C., Hakim-Larson, J, \& Hayden, M. (1983, April). Contexts of logic: The growth of interpretation from pre-adolescence to mature adulthood. Paper presented at the biennial meeting of the Society for Research in Child Development, Detroit, MI.

Laville, C. (2004). Historical consciousness and historical education: What to expect from the first for the second. In P. Seixas (Ed.), Theorizing historical consciousness (pp. 165-182). Toronto, Ontario, Canada: University of Toronto Press.

Ledbetter, B. (1986). The resolution of relativism in adult thinking: Subjective, objective, or conceptual? Human Development, 29, 291-300.

Lenkauskaite, J., \& Mazeikiene, N. (2012). Challenges of introducing problem-based learning (PBL) in higher education: Selecting problems and using problems. Social Research, 2(27), 78-88.

Marchand, H. (2002). Some reflections on postformal thought. The Genetic Epistemologist. Retrieved from http://www.tiac.net/ commons/Some\%20Reflections\%20on\%20Postformal\%20Thought.html.

Maxwell, N. L, Bellisimo, Y, \& Mergendoller, J. R. (2001). Problem-based learning: Modifying the medical school model for teaching high school economics. The Social Studies, 92(2), 73-78.

Mayring, P. (2000). Qualitative content analysis. In Forum: Qualitative Social Research, 1(2) Article 20, http://nbnresolving.de/urn:nbn:de:0114-fqs0002204.

Mergendoller, J. R., Maxwell, N. L., \& Bellisimo, Y. (2006). The effectiveness of problem-based instruction: A comparative study of instructional methods and student characteristics. International Journal of Problem-Based Learning, 1(2), 4969.

Perry, W. G., Jr. (1970). Forms of intellectual and ethical development in the college years: A scheme. New York, NY: Holt, Rinehart, and Winston.

Potter,W. J., \& Levine-Donnerstein, D. (1999). Rethinking validity and reliability in content analysis. Journal of Applied Communication Research, 27, 258-284.

Reisman, A., \& Wineburg, S. (2008). Teaching the skill of contextualizing history. The Social Studies, 99(5), 202-207.

Riegel, K. F. (1975). Toward a dialectical theory of development. Human Development, 18, 50-64.

Samuals, M., \& Espar, D. (2011). The American experience: The triangle fire. Arlington, VA: Public Broadcasting Service.

Samuals, M., \& Goodman, B. (2010). The American experience: My Lai. Arlington, VA: Public Broadcasting Service.

Samuals, M., \& Stone, R. (2009). The American experience: The civilian conservation corp. Arlington, VA: Public Broadcasting Service.

Sinnott, J. D. (1989). A model for solution of ill-structured problems: Implications for everyday and abstract problem solving. In J. D. Sinnott (Ed.), Everyday problem solving: Theory and applications (pp. 72-99). New York, NY: Praeger.

Sinnott, J. D. (1998). The development of logic in adulthood: Postformal thought and its applications. New York, NY: Plenum Press.

Sinnott, J. D., \& Johnson, L. (1996). Reinventing the university: A radical proposal for a problem-focused university. Norwood, NJ: Ablex.

Sinnott, J. D., \& Johnson, L. (1997). Brief report: Complex postformal thought in skilled administrators. Journal of Adult Development, 4(1), 45-53.

Sipress, J. M., \& Voelker, D. J. (2011). The end of the history survey course: The rise and fall of the coverage model. The Journal of American History, 97(4), 1050-1066.

Stearns, P. N. (1993). Meaning over memory: Recasting the teaching and culture of history. Chapel Hill, NC: University of North Carolina Press.

Steinberg, L. (2007). Risk taking in adolescence: New perspectives from brain and behavioral science. Current Directions in Psychological Science, 16, 55-59.

VanSledright, B. A. (2014). Assessing historical thinking and understanding. New York, NY: Routledge.

Voelker, D. J., \& Armstrong, A. (2013). Designing a question-driven U.S. history course. OAH Magazine of History, 27(3), 1924.

Vukman, K. B. (2005). Developmental differences in metacognition and their connections with cognitive development and adulthood. Journal of Adult Development, 12(4), 211-221.

Westhoff, M. W. (2013). A perfect storm and the U.S. history survey. OAH Magazine of History, 27(3), 3-4.

Witteman, C., van den Bercken, J., Claes, L., \& Godoy, A. (2009). Assessing rational and intuitive thinking styles. European Journal of Psychological Assessment, 25(1), 39-47.

Wu, P., \& Chiou, W. (2008). Postformal thinking and creativity among late adolescents: A post-Piagetian approach. Adolescence, 43(170), 237-251.

Wynn, C. T. (2010). Promoting cognitive growth through problem-based instruction in a first-year learning community. Journal 
of Learning Communities Research, 5(2), 5-15.

Wynn, C. T. (2015). A cognitive rationale for a problem-based U.S. history survey. Teaching History: A Journal of Methods, $40(1), 28-42$.

Wynn, C. T. (n.d.). HIST 2112 problem-based activities. Retrieved from https://www.taskstream.com/ts/wynn3/HIST2112ProblemBasedActivities (Password: Wynn1)

Wynn, C. T., Mosholder, R. S., \& Larsen, C. A. (2014). Measuring the effects of problem-based learning on the development of postformal thinking skills and engagement of first-year learning community students. Learning Communities Research and Practice, 2(2), Article 4. Retrieved from http://washingtoncenter.evergreen.edu/lcrpjournal/vol2/iss2/4 


\section{APPENDIX A}

\section{HIST 2112 PBL Instructional Units}

Unit 1 - Political Dynamics of the 1890 s

Unit 2 - The U.S. as an Empire: Global Power Structure (1890-1905)

PBL Activity - The Question of U.S. Expansion: Expansionists versus Anti-Expansionists

Unit 3 - Social and Political Dynamics in the Progressive Era

Unit 4 - The Nation at War

PBL Activity - Wilson and the Paris Peace Conference: Constructing the Treaty of Versailles - The full activity, including detailed procedures, materials, assessments, rubrics, and Power Point slides may be accessed at http://tinyurl.com/wynnpbl2, password: PBL2.

Unit 5 - Economic Expansion of the 1920s, The Depression, Franklin D. Roosevelt and the New Deal

PBL Activity - Solving the Problems of the Depression: Constructing the New Deal

Unit 6 - America and the World (1921-1945)

PBL Activity - The Atomic Bomb: Truman's Decision and Its Impact

\section{The Post War Era and Beyond - 1945 to Present}

Unit 7 - The Cold War and Beyond (includes current foreign policy challenges)

Unit 8 - Civil Rights in the U.S.: Tracing Social, Economic, and Political Dynamics in the Last Half of the $20^{\text {th }}$ Century PBL Activity - The Issue of Affirmative Action: The Atlanta Case

Each of the above activities may be accessed at https://www.taskstream.com/ts/wynn3/HIST2112ProblemBasedActivities, password: Wynn1.

Unit 9 - Challenges of the New Century PBL Activity - Student Decisions on Current Issues: The Affordable Care Act; Immigration Reform; Debt, Spending, Taxes, and a Balanced Budget Amendment; Climate Change and Cap \& Trade; Minimum Wage. 


\section{APPENDIX B}

Metacognitive Reflection Questionnaire (Adapted from Wynn et al., 2014)

Please respond to each statement below by circling the number that best describes the thinking/reasoning you used during this activity.

$1=\operatorname{Never}(\mathrm{N})$

$4=$ Somewhat Often $(\mathrm{SO})$

$$
\begin{aligned}
& 2=\text { Rarely }(\mathrm{R}) \\
& 5=\text { Often }(\mathrm{O})
\end{aligned}
$$

$3=$ Occasionally $(\mathrm{S})$

$6=$ Very Often $(\mathrm{VO})$

\section{$\underline{N} \quad \underline{R} \quad \underline{S} \quad \underline{S O} \quad \underline{O} \quad \underline{V O}$}

1. I used intuitive or emotional thinking (It felt right.) as I made a decision on this problem/issue. (Intuitive Thinking)

$\begin{array}{llllll}1 & 2 & 3 & 4 & 5 & 6\end{array}$

2. I used logical-analytical thinking (application of logical operations) to develop correct solution as I made a decision on this problem/issue. (Formal Thinking)

$\begin{array}{llllll}1 & 2 & 3 & 4 & 5 & 6\end{array}$

3. I considered context, multiple causes, multiple points of view, and conflicting ideas about what is true and relevant related to this problem/issue as I reached a conclusion or decision. (Postformal Thinking: Relativistic)

$\begin{array}{llllll}1 & 2 & 3 & 4 & 5 & 6\end{array}$

4. I searched for and used inconsistencies and contradictions inherent in this problem/issue, sought to understand why those contradictory perspectives exist, and sought to resolve those contradictions as part of the problem-solving process. (Postformal Thinking: Relativistic/Dialectical)

$\begin{array}{llllll}1 & 2 & 3 & 4 & 5 & 6\end{array}$

5. I recognized that often there is no "correct" answer when dealing with complex problems/issues like this one. (Postformal Thinking: Relatistic/Dialectical)

$$
\begin{array}{llllll}
1 & 2 & 3 & 4 & 5 & 6
\end{array}
$$

6. I considered how change could affect this problem/issue and possibly my opinion/decision. (Postformal Thinking: Dialectical)

$\begin{array}{llllll}1 & 2 & 3 & 4 & 5 & 6\end{array}$

Please respond to the following question on the back of this questionnaire.

7. Describe the various thinking systems you utilized during this problem-based activity, (from those listed above, and from more discipline specific processes like historical thinking, mathematical computation/estimation, etc.) How significant were these processes in helping you solve the problem or make a decision? 


\section{APPENDIX C}

Complex Postformal Thought (PFT) Questionnaire (Sinnott \& Johnson, 1997)

The Complex Postformal Thought Questionnaire is reprinted with permission from Springer Publishing Company.

Please respond to each item below by circling the number that best describes you on the following scale:

$1=$ Not True (of self) and $7=$ Very True (of self).

1. I see the paradoxes in life (Paradoxes are inherent contradictions in reality.)

$\begin{array}{llllllll}1 & 2 & 3 & 4 & 5 & 6 & 7\end{array}$

2. I see more than one method that can be used to reach a solution or decision on a problem or issue.

$\begin{array}{llllllll}1 & 2 & 3 & 4 & 5 & 6 & 7\end{array}$

3. I am aware that I can decide which reality or truth to experience at a particular time; but I know that reality and truth is really multi-level and more complicated.

$\begin{array}{lllllll}1 & 2 & 3 & 4 & 5 & 6 & 7\end{array}$

4. There are many "right" ways to define any life experience; I must make a final decision on how I define the problems of life.

$\begin{array}{lllllll}1 & 2 & 3 & 4 & 5 & 6 & 7\end{array}$

5. I am aware that sometimes "succeeding" in the everyday world means finding a concrete answer to one of life's problems; but sometimes it means finding a correct path that would carry me through any problems of this type.

$\begin{array}{llllllll}1 & 2 & 3 & 4 & 5 & 6 & 7\end{array}$

6. Almost all problems can be solved by logic, but this may require different types of "logics."
12
3
4
56
7

7. I tend to see several causes connected with any event.

$\begin{array}{llllllll}1 & 2 & 3 & 4 & 5 & 6 & 7\end{array}$

8. I see that a given dilemma always has several good solutions.

$\begin{array}{llllllll}1 & 2 & 3 & 4 & 5 & 6 & 7\end{array}$

9. I realize that I often have several goals in mind, or that life seems to have several goals in mind for me. So I go toward more than one in following my path in life.

$\begin{array}{llllllll}1 & 2 & 3 & 4 & 5 & 6 & 7\end{array}$

10. I can see the hidden logic in others' solutions to the problem of life, even if I don't agree with their solutions and follow my own path.

$\begin{array}{llllllll}1 & 2 & 3 & 4 & 5 & 6 & 7\end{array}$




\section{APPENDIX D}

End of Study Questions (Wynn et al., 2014)

Title of the Research Study: The effect of problem-based learning and metacognitive reflection on the development of postformal thinking among U.S. history survey students

Thank you for participating in this study. Please answer the 5 questions below based on your experience this semester in HIST 2112.

1. Rank your level of engagement (active participation) in this course.

$(1=$ not engaged, 5 = fully engaged $)$.

$\begin{array}{lllll}1 & 2 & 3 & 4 & 5\end{array}$

Explain your response.

2. How does your ranking of engagement in this course compare to other history/psychology courses you've taken (in college or high school)?

Explain your response.

3. Rank the level of relevancy of the content of this course. How relevant were the topics (content areas)?

$(1=$ irrelevant, $5=$ very relevant $)$.

Explain your response.

4. Do you believe you have expanded your ability to think critically as a result of this course? If so, can you explain the how your thinking has changed and/or evolved?

5. To what extent do you believe you may utilize the thinking skills you may have gained in this course as you continue your education and life in general?

Explain your response. 


\section{APPENDIX E}

Operational Definitions: Closed Systems (CS) and Postformal Operational (PF) (Wynn et al., 2014)

CS can be identified by the following characteristics:

- Focus on a limited number of aspects to the exclusion of other potentially useful aspects

- Use of a familiar problem solving framework

- Expectation of a single right answer applicable to all similar circumstance

Analytical/Formal (Closed Systems) Problem-Solving - A closed systems problem-solver will generally apply a practiced systematic/formal problem-solving framework based on previous experience with similar problems to solve the problem at hand. This framework involves a problem-solving dynamic based on a limited number of variables, with other important aspects of the problem often judged as irrelevant to the solution. This causes formal thinkers to expect to produce a single right answer that will apply to all similar circumstances.

People are using PF when they recognize some or all of the following:

- What is considered to be true can change when perspective and context change

- Contradictions are often critical to understanding the complexities of a problem

- The sides surrounding contradictions are interrelated and must be accommodated in the development of resolution alternatives

- Some problems and issues don't have simple and neat solutions

- Even though a solution to a messy, real-life problem is identified, there will always be new challenges as the world and the people involved change.

Postformal Problem-Solving - Relativistic thinkers recognize that as a person's perspective or context changes, so too does her/his perspective on what is true. Rather than seeing problems and issues through the lens of fixed truths, and/or good vs. bad, relativistic thinkers recognize that context and contradictions are key to understanding the complexities of a problem, developing potential resolution alternatives, and recognizing the fact that no resolution may be possible for some problems and issues.

Dialectical thinking involves the integration of relativistic thinking with the recognition that both sides of contradictions within a problem/issue are interrelated and connected and are critical in the development of resolution alternatives. Inconsistencies and contradictions within problems and issues become catalysts in the application of multiple cognitive systems as dialectical thinkers seek resolutions that lead to higher levels of understanding and cognition. Dialectical thinkers also recognize that any resolution or stability that may result from dialectical problem-solving operations will be perpetually challenged by new challenges, changes, and a potential tension-to resolution-to tension cycle dynamic. 


\section{APPENDIX F}

Sampling of Student Comments from ESQ Questions

Sample PBL Student Comments from ESQ Questions Four or Five (PFT Experience):

- Student \#19-PBL Section 1 - "I personally have never really been a person to pick sides and this class only strengthened that. I was reminded that both sides of an argument may have very valid points. One other way that I feel like I have gotten better is collaborating with others to make a better solution. It is silly to debate about something and not come up with a solution. I learned how to reach a solution with people who have very different viewpoints than me."

- Student \#20-PBL Section 1 - "Yes. I can look at more than one view point. I can look beyond gut thinking. I can understand why opposing views think the way they do and use their perspective in my thinking toward a solution. I will use this in all aspects of my life. It is a great thing to have and utilize."

- Student \#35-PBL Section 2 - "Yes. I can now look at both sides before I make a decision. Both sides have a point and both points need to be viewed before making a decision. I believe I will use this for the rest of my life. I learned to stop and think before doing anything and to look into both views."

- Student \#39-PBL Section 2 - "Yes. Before, if I had an opinion I would only look at it from my point of view and I would automatically think I believe the other side is wrong. This class made me look at both sides critically and then come up with a decision.

- Student \#71-PBL Section 3 - "Yes. I believe this course has allowed me to expand my thinking skills very much. As a result of this course, I have understood that there are several possible solutions to complicated problems. Moreover, it has taught me to think critically about problems and understand multiple sides."

- Student \#85-PBL Section 3 - "Yes. [The instructor] made us realize that here are always more points of view other than our own. For example, the activity about the end of WWI and how to punish Germany showed me Germany's side for the first time ever. Our class was able to find compromise in every situation we were given. It makes me wonder how our government fails to do the same."

Sample TLD Student Comments from ESQ Questions Four or Five (PFT Experience):

- Student \#105-TDL Section 1 - "I have expanded my thinking because I see and understand different reasons for why things happened the way they did, and how some things could have been prevented. I can listen to and respect others' opinions even if I disagree."

- Student \#152-TDL Section 1 - "I utilized some of the perspectives focused on in this course to try to see problems from different points of view."

- Student \#259-TDL Section 2 - "I think so. I've learned there's hidden sides to a lot of different things and situations"

- Student\#336-TDL Section 2 - "Yes. Since one of the main course themes was rhetoric vs. reality, it makes me question more things in our society and try to dive deeper into where these problems originated."

Sample PBL Student Comments from ESQ Question One (Engagement):

- Student \#5-PBL Section 1 - "I was actively forming opinions on subjects through information presented by classmates as well as my instructor, unlike previous courses I have taken where all information presented comes from a singular source, the teacher."

- Student \#6-PBL Section 1 - "When we did activities involving what we would do in certain situations, I was fully engaged. I was also fully engaged when learning about current issues."

- Student \#33-PBL Section 2 - "I always felt like I was fully involved in the course, not only because of the way we had to come up with solutions after analyzing the situations/problems, but also because of the way the lecture was presented." 
- Student \#34-PBL Section 2 - "This class was constantly challenging my beliefs and had me actively thinking about why I believe what I believe. The class was very engaging.

- Student \#64-PBL Section 3 - "Five. Professor has us analyze situations and asks us to come up with solutions that we share in class."

- Student \#78-PBL Section 3 - "Always on the edge of my seat in this class - love hearing both sides of any given point."

Sample TLD Student Comments from ESQ Question One (Engagement):

- Student \#136-TLD Section 1 - "I came to almost every class this semester except maybe two. I take notes and have done well on the tests. If I wasn't engaged, I would not be doing well."

- Student \#178-TLD Section 1 - "I feel like I have been very engaged because I have only missed one class due to unforeseen circumstances, and pay attention/take notes every class period."

- Student \#225-TLD Section 2 - "I feel engaged with the material I am learning because [my professor] has taught me the material from different angles and perspectives not known to me. Another thing is that he is very knowledgeable and is an intellectual man in nature."

- Student \#291-TLD Section 2 - "I attended all but two class sessions, read the textbook for roughly half of the semester. I paid attention to lectures and took notes, but didn't' often raise my hand to answer questions because of shyness or not knowing the answer to a question." 


\section{NOTES}

